DOI: https://doi.org/10.15407/techned2018.04 $\leq \underline{094}$

\title{
THE MANEUVER-NEW SYSTEM'S USE FOR PROBLEMS SOLVING OF THE OPTIMAL LOADING OF THE THERMAL POWER PLANTS' UNITS
}

Journal

Publisher

ISSN

Issue

Pages
Tekhnichna elektrodynamika

Institute of Electrodynamics National Academy of Science of Ukraine 1607-7970 (print), 2218-1903 (online)

No 4, 2018 (July/August)

$94-97$

\section{Authors}

O.V. Fesiuk ${ }^{1 \star}$, P.I. Stetsyuk ${ }^{2 \star \star}$, O.F. Butkevych ${ }^{3 \star \star \star}$

1,2 - Glushkov Institute of Cybernetics of the National Academy of Sciences of Ukraine,

40 Glushkov ave., Kyiv, 03187, Ukraine,

e-mail: sasha.fesyuk@gmail.com

3 - Institute of Electrodynamics National Academy of Sciences of Ukraine,

pr. Peremohy, 56, Kyiv, 03057, Ukraine,

e-mail: butkevych@ied.org.ua

* ORCID ID : http://orcid.org/0000-0002-9308-0083

** ORCID ID : http://orcid.org//0000-0003-4036-2543

*** ORCID ID : http://orcid.org/0000-0002-6613-0911

\section{Abstract}

Functionality features of the web-based system Maneuver-New that is designed for solving integer-valued, linear, and nonlinear programming problems, and its using for finding the optimal load of power units of thermal power plants are described. The results of comparison of 
the obtained solution of the test task with the solution published abroad are presented. These results testify to the advantages of the developed Maneuver-New system. References 8, figures 2 , tables 2.

Key words: thermal power plants units' optimal loading, ED- and UC-problems, NEOS-server, $r$ algorithm.

Received: 02.03.2018

Accepted: 20.03.2018

Published:

\section{References}

1. Butkevych O.F., Rybina O.B. Optimization problems of the dispatcher control of territorially-distributed electric power objects and synthesis of the means for their solving. Tekhn ichna Elektrodynamika

. 2000. Temat. vypusk Problemy suchasnoi elektrotekhniky. Part 3. Pp. 99-103. (Rus)

2. Stetsyuk P.I. Methods of ellipsoids and r-algorithms. Chisinau: Evrika, 2014. 488 p. (Rus)

3. Hassan Z.G., Ezzat M., Abdelaziz A.Y. Solving unit commitment and economic load dispatch problems using modern optimization algorithms. International Journal of Engineering, Science and Technology 2017. Vol. 9. No 4. Pp.

10-19. DOI: https://doi.org/1

\subsection{4 /ijest.v9i4.2}

4. NEOS Server: State-of-the-Art Solvers for Numerical Optimization. URL: https://neos-serve r.org/neos/

5. Shor N.Z. Minimization Methods for Non-Differentiable Functions. Berlin: Springer-Verlag, 1985. 178 p. DOI: https://doi.org/10.1007/978-3-642-82118-9

6. Tung N.S., Bhadoria A., Bhardwaj A. Start up Cost constraint Optimization using Lagrangian 
Algorithm for Unit Schedule in Electrical Power System. International Journal of enhanced research in Science Technology \& Engineering

. 2013. Vol. 2. Issue 1. Pp. 1-7.

7. Yuan X., Wang L., Zhang Y., Yuan Y. A hybrid differential evolution method for dynamic economic dispatch with valve-point effects. Expert Systems with Applications. 2009. Vol. 36. Pp. 4042-4048. DOI:

https://doi.org/10.1016/j.eswa.2008.03.006

8. Zivic Djurovic M., Milacic A., Krsulja M. A simplified model of quadratic cost function for thermal generators. Proceedings of the $23^{\text {rd }}$ International DAAAM Symposium. 2012. Vol. 23.

No 1. Pp. 25-28.

PDF 